\title{
Bureaucrats or Markets in Innovation Policy? - a critique of the entrepreneurial state
}

\author{
Nils Karlson ${ }^{1} \cdot$ Christian Sandström $^{2} \cdot$ Karl Wennberg $^{3}$
}

Published online: 23 April 2020

(C) The Author(s) 2020

\begin{abstract}
This paper takes stock of recent suggestions that the state apparatus is a central and underappreciated actor in the generation, diffusion and exploitation of innovations enhancing growth and social welfare. We contrast such a view of "the entrepreneurial state" with theories and empirical evidence of the microeconomic processes of innovation in the modern economy which focus on well-functioning markets, free entry and competition among firms, and independent entrepreneurship as central mechanisms in the creation and dissemination of innovations. In doing so, we identify several deficiencies in the notion of an entrepreneurial state by showing that (i) there is weak empirical support in the many hundreds empirical studies and related meta analyses evaluating the effectiveness of active industrial and innovative policies, that (ii) these policies do not take account of the presence of information and incentive problems which together explain why attempts to address purported market failures often result in policy failures, and that (iii) the exclusive focus on knowledge creation through $\mathrm{R} \& \mathrm{D}$ and different forms of firm subsidies ignores the equally important mechanisms of knowledge dissemination and creation through commercial exploitation in markets. We discuss how a more theoretically well-founded focus on the state as investing in knowledge generation and securing the conditions of free and competitive markets will lead to a more innovative economy.
\end{abstract}

Keywords Innovation policy $\cdot$ Market failure $\cdot$ Entrepreneurial state $\cdot$ Incentive problem . Rent seeking

JEL codes $\mathrm{O} 31 \cdot \mathrm{O} 38 \cdot \mathrm{P} 16$

\section{Introduction}

How innovation can best be promoted is a question that developed and developing countries alike seek to answer in order to enhance competitiveness, productivity,

Nils Karlson

nils.karlson@ratio.se

Extended author information available on the last page of the article 
employment, growth and sustainable development. For decades, governments have used active industrial policies seeking to steer investments in the economy to specific sectors or firms thought to be 'leaders of the future' or 'future growth sectors'. Later years have seen a renewed call for the active industrial policies of the 1980s throughout developed and developing economies alike. Today's such policies go under different names. Sometimes they are called innovation policies, sometimes industrial policies. Increasingly, they go under the name of environmental policies. For example, the EU Commission in January 2020 proposed a program called the European Green Deal Investment Plan, also referred to as the 'Sustainable Europe Investment Plan'. The Plan is supposed to "mobilise" at least $€ 1$ trillion in investments over the next decade through the EU budget and associated instruments (Commission 2020). Most developed countries have similar programs and initiatives.

All these investments of tax money beg the question to what extent centrally placed public coordinators (bureaucrats) or decentralized and competitive markets should be central to innovation policy? That is the key question in our paper. The paper leans on our recent book with the same title and results from a major interdisciplinary research program (Financing of Innovation) conducted at the Ratio Institute in Sweden between 2013 and 2018.

Our paper is structured as follows: we first briefly review competing perspectives on innovation policy in the literature, next we discuss a key assumption for the argument of bureaucrats as central actors in innovation policies - that notion of 'market failures'. Third, we review stylized empirical evidence on the ineffectiveness of public support schemes for innovation, showing that overall, such support schemes have a poor record in terms of affecting innovation outcomes. We outline empirical evidence and theoretical arguments that such support schemes are based on faulty theoretical premises in that market failures in innovation are not the key impediment for innovations in society. Based on research in innovation economics we argue that research and public policy needs to shift from an exclusive focus on knowledge creation through $\mathrm{R} \& \mathrm{D}$ and different forms of firm subsidies to a focus on knowledge dissemination and creation through commercial exploitation in free and competitive markets.

\section{Competing perspectives on innovation policy}

Advocates of industrial and innovation policies thus most often given the government a major role in the promotion of innovations, sustainable development and the like. One such example is Mazzucato's book The Entrepreneurial State (2015) which argues the state's role in innovation has been greatly underestimated. Using examples primarily from the US to show different cases where the state rather than firms started the development of aviation, nuclear energy, computers, the internet, the biotechnology revolution, nanotechnology, and various environmental technologies, she then argues that the state should take the lead in developing strategies for key sectors and technologies. Scholars have pointed out a collection of problems with Mazzucato's argument. First, Mazzucato's view confuses invention with innovation as the iPhone and its social and economic value was an entrepreneurial discovery made in the marketplace, not in the laboratory. Second, her argument is at best anecdotal, but even the anecdotes contain several rather serious factual errors (Sandström 2015). Third, the book does not try to infer any causality and it avoids 
attempts at a cost-benefit assessment of public interventions while nevertheless making bold claims about the government's positive net contribution (Potts et al. 2016).

Contemporary theoretical accounts of the microeconomic processes of innovation in the modern economy have been outlined by e.g. William Baumol, David Audretsch, and Zoltan Acs. A key distinction between these theories and the view sketched by Mazzucato is the focus on well-functioning markets, free entry and competition among firms, and above all the role of entrepreneurship as a central mechanism in the creation and dissemination of innovations. In Baumol's (2002) The Free-Market Innovation Machine, the role of entrepreneurship and small firms is recognized, but it is also emphasized that the bulk of innovative activity is carried out by large, oligopolistic firms that compete neck to neck with each other through constantly launching new innovations. He compares this to an arms race in which no major firm dares to fall behind the others. However, since innovation (R\&D) is costly, and can be made obsolete by rival innovation, firms split the costs through the sale of technology licenses and participation in technology-sharing agreements, which he sees as a natural and desirable outcome of the actions of profitseeking firms operating in (imperfectly) competitive markets. Also, innovation tends to breed new innovations, through spill overs of various sorts. This process, in Baumol's view, accounts for the unparalleled growth of modern capitalist economies.

In Audretch and Acs's theory - which has been developed in a series of well-cited articles and books since the early 1980s and summarized in Audretsch's The Entrepreneurial Society (2008) - the role of new entrepreneurial firms as the origin of innovation takes central stage. The authors offer an economic explanation to this question based on an agency cost perspective (Acs 2002; Audretsch 1995; Audretsch and Baumol 2001; Wiggins 1995) as they argue that in the absence of perfect markets with perfect information, markets are characterized by uncertainty and substantial information asymmetries which make the creation of new independent firms the best way to process the information needed to determine the value of new opportunities. Due to the uncertain nature of economic knowledge, and the existence of substantial information asymmetries across agents, the assessment of the expected value of a new means-ends framework is likely to be anything but unanimous between the entrepreneur and the decision makers of the incumbent actors.

These contemporary theories of innovation to a large extent correspond to the classical contributions of (the early) Schumpeter, Hayek and Kirzner about how free markets contribute to growth and new knowledge. According to Schumpeter (1934) economic development is precisely the result of innovative entrepreneurship, that is, the commercialization of new, productive knowledge in a broad sense. Hayek (1945), in perhaps his major contribution to economic theory, emphasises that market competition works as a discovery procedure that make the use knowledge otherwise not known available to the economic actors. Kirzner (1973), in a sense, combines the two by showing that the uncertainty that characterizes new ventures and innovation can only be handled by entrepreneurs in competitive markets. Note, moreover, market competition for these authors, just as for Baumol, includes "imperfect" or oligopolistic competition in the neoclassical sense.

The stark distinctions between 'top-down' views on innovation in society such as Mazzucato's The Entrepreneurial State, and more bottom-up perspectives emphasizing the competitive dynamics on free markets as the central mechanism in the creation and dissemination of innovations implies that a further investigation of how these 
contrasting perspectives inform policy. In the next section, we delve deeper into the notion of market failures, which is critical in the realm of innovation policy.

\section{The straw man argument of 'market failures' in legitimizing interventions}

Modern industrial policies and in particular innovation policies tend to draw legitimacy from the economic theory of market failures which highlights that a market-based system may lead to welfare-suboptimal investments in research and development (R\&D) (Arrow 1962). This well accepted theory explains why a free-market system with no or limited intellectual property protection may lower incentives for private actors to invest in producing new knowledge, and hence that knowledge creation in society will be below a welfare-generating social optimum (Klette et al. 2000).

The overarching policy idea - derived directly from Arrow's argument- is that innovation has public good characteristics, and therefore needs to be publicly supported. However, proponents of active industrial policy and in particular of targeted innovation policies tend to overinterpret the theory as saying that in the absence of such government support, innovation will be undersupplied, and therefore the government is likely to play an instrumental role in innovation (Mazzucato 2015).

Market failure theory thus defines the innovation problem as an allocation problem that can be resolved through various instruments to correct the misallocation of resources. These instruments range from direct public support (e.g. public science or government grants), indirect subsidy (R\&D tax credits), or by creating high-powered incentives for private investment (e.g. through intellectual property rights).

One should note that Arrow does not discuss interventions as a necessary and sufficient condition to address the public goods nature of new (innovative) knowledge. This is but one of the policy tools available to incentivize private sector knowledgegeneration. Removing regulations and impediments to new firm entry and competition with incumbents (Djankov et al. 2002) or designing intellectual property legislature that incentivize $R \& D$ and in particular high-risk $R \& D$ are equally potent policy conclusions from the theory (Shapiro 2001). Further, an exclusive focus on the knowledge generation problem through $\mathrm{R} \& \mathrm{D}$ and the like is insufficient for promoting innovationdriven growth. Equally important is attention to knowledge dissemination and creation through market competition. While this is not the focus of Arrow's argument, it is a necessary cornerstone of any wholesome theory of innovation in society as well as public policy on this topic. We return to discuss research on the mechanisms of, and impediments to, knowledge dissemination in the below. First, one needs to take stock of the accumulating evidence regarding various policies for fostering innovation based on the theoretical premise of market failures.

\section{The ineffectiveness of government support schemes: Empirical evidence}

Since at least the 1970s, governments around the globe have implemented policies seeking to enhance innovation in the private sector, many targeted towards the funding 
of new innovative firms. These policies range from direct subsidies, tax cuts (directed especially at new or small firms), special grants for working capital, business training, and counselling services, etc. A sizeable portion of such innovation policies seek to provide financial resources such as public loans or grants (Brown and Earle 2017). Through such policy interventions (also referred to as "input-related" policies), governments seek to provide support aimed at narrowing the knowledge and resource gaps entrepreneurs face as they launch and run their firms. Implicit in these interventions is an effort to address presumed market failures for these entrepreneurs to close these knowledge and resource gaps themselves (Audretsch 2008). Given the resources devoted to business support programs, it is natural to ask whether these interventions ("inputs") are effective at growing successful ventures ("outputs").

To determine whether public support schemes - direct as e.g. in subsidies and tax relief, or indirect as e.g. in training interventions - for firms are effective, careful empirical work is needed. However, carrying out empirical evaluations of selective support/subsidies is often a difficult challenge since these are unfortunately rarely distributed in such a way that they can be systematically evaluated. A common practice in many government support schemes is to distribute funds to firms that actively seek and qualify for such support. Such firms differ from other firms in several ways: They can be more successful than other firms as they passed an evaluation to receive their support, or they may be less profitable than other firms, as they needed to apply for public support. This makes it difficult to study whether the intended effect of support schemes work since the counterfactual - what would have happened to the firm without the public support is theoretically and methodologically thorny to identify. Another problem for government efforts is to prevent their interventions from crowding out the availability of resources already provided by market mechanisms (e.g. Cumming and Groh 2018). For example, if authorities offer lenient loans, support, or other measures on more favorable terms than the private sector, there is a risk that firms simply replace private money with public money without a net increase in the amount of capital. Given these evaluation problems, it is not surprising that the empirical results from assessments of policies seeking to increase the amount or quality of innovation in firms are highly scattered.

The most broad-ranging policies seeking to address the underinvestment in R\&D highlighted by Arrow (1962) are based on various tax credits schemes. However, metaanalyses of $R \& D$ tax credits and $R \& D$ grants unanimously show that effects are very scattered across various studies, and few conclusions can be drawn about their potential effectiveness (e.g. Dimos and Pugh 2016; García-Quevedo 2004) A recent OECD survey finds that "it is unclear whether the social benefits [of R\&D tax support] outweigh the costs" (Box 2009, p.9). International experience of R\&D support and similar policies suggests these to be highly context dependent and difficult to generalize from (Sandström et al. 2016). For example, a study of Israeli innovation support found positive effects on small firm, but negative if support was given to large firms (Lach 2002). A German study indicated that support did increase private firms' R\&D investments (Hussinger 2008). A study of US R\&D support for small firms found that support primarily crowded out private money and did not produce any positive effects (Wallsten 2000), while recent studies of the same program did find positive effects on the innovativeness of energy firms (Howell 2017). Overall, results seem to differ depending on the method used, the sector and region that is subsidized, and how subsidies are distributed (Colombo and Grilli 2011). 
A literature review summarizing 77 different studies of government support schemes reveal scattered results and that many published studies suffer methodological problems, partly related to the prevalence firms that benefit from multiple supporting activities (Zúñiga-Vicente et al. 2014). Evaluating efforts where firms receive more than one type of support is methodologically complicated. When firms have received several support initiatives, it becomes difficult to distinguish which of the supports had a possible effect, if there are competing effects, or if effects arise cumulatively. One of the countries with the longest history of offering a range of policies in support of entrepreneurship is the United Kingdom. In a long-term study of various UK government initiatives to support new and small firms, Bennett (2008) surveyed more than 2000 firms in 1991, 1997, 2002, and 2004, finding that, overall, government intervention is difficult to make effective at reasonable cost-benefit ratios. Bennett finds little evidence of market failure for growing and more innovative firms, but rather than systemic market failures in the United Kingdom only seems to influence very earlystage start-ups. Over the study period, the UK government partly decentralized previously centralized programs, which had marginal benefits for the number and type of recipient firms on the one hand, but sharply increased public costs and the bureaucracy recipient firms had to negotiate on the other. Bennett's survey also highlights the stark gender bias in a highly disproportionate number and sum of support provided to maleled firms, compared to the average level of male- and female-led small and new firms.

Policies enacted are also highly heterogenous. Some government support comes in the form of free or subsidized advisory services, rather than as financial support. A recent study by Widerstedt and Månsson (2015) examined the effect of business counseling support from a 2004-2007 Swedish grant program, aimed at firms in peripheral regions, in which 1244 firms that applied for and received advice were compared to more than 90,000 control group firms in a matched sample. The authors found that while value added and number of employees seemed to increase more rapidly for firms that received advice compared to the control group, this effect was mainly due to increased use of labor and capital rather than increased efficiency, and the differences disappeared when self-selection of firms seeking advice was controlled for.

Other government support comes in the form of subsidized or wholly funded incubators and science parks where firms can apply for subsidized facilities, business advice, networking support, etc. What makes such incubators more (or less) successful has been amply studied in the innovation literature (e.g. Bruneel et al. 2012; Klofsten et al. 2020). However, studies that identify whether incubation is actually, on average, advantageous for beneficiaries and a cost-effective way for society as a whole to foster the creation of new innovative firms are scarce. Recent evidence from the United States, Italy, and Germany suggest that incubators are very heterogenous and that, on average, incubated firms perform no better than comparable non-incubated firms when their support comes to an end ((e.g. Amezcua 2010; Lukeš et al. 2019; Schwartz 2013). A recent comprehensive study of "the Swedish incubator program" - a governmental program overseeing the overall financial support and management of more than 40 incubators across Sweden examined how incubation affects performance of participating firms as well as innovativeness in terms of patenting among individuals managing or employees (Ejermo 2018). Comparing 296 CEOs and 2585 employees in incubated firms with a matched sample of comparable individuals in similar (non-incubated) firms in 2005-2014, Ejermo found that while incubation did not foster turnover growth 
or value added among participating firms, incubation did seem to foster innovativeness in the form of patenting activity among CEOs of incubated firms. For employees, there was only a small effect on increased patenting.

Further, it appears that the support schemes can distort firm behavior. Due to the prevalence of public support systems for innovation within countries where different authorities distribute various types of support - often with no or little coordination between the authorities - firms may systematically seek and obtain several grants for related purposes. Not only do this makes evaluations of various policies challenging (Zúñiga-Vicente et al. 2014) but it also creates a potential market for rent-seeking activities. Firms that are good at securing public grants may in theory be drawn from any tail in the productivity distribution but in practice authorities seek to foster 'highpotential firms' where they seem potential for growth and productivity improvement, meaning that below-average productive firms may easily be lured into a habit of applying for grants and public support rather than seeking to improve their productivity and gain market shares. Such firms in a sense becoming "subsidy entrepreneurs" with lingering low long-term productivity but still being able to hire skilled workers and pay them well, at least for the intermediate time horizon (Gustafsson et al. 2019). If grants designed to stimulate innovation instead led to some firms simply specializing in getting grants this may in time create an increasing market for unproductive or even destructive entrepreneurship that compete unfairly with non-subsidies firms (Baumol 1990).

Some argue that effects on innovation can only be seen in hindsight when sufficient time has elapsed. In a study conducted by parts of the coauthor team, however, the only noticeable effects are short term in the form of a 'sugar rush' when grants recipients are able to overspend on equipment and new staff (Gustafsson et al. 2016). Over time, the effects fade away. Lerner (2009, p.5) summarized extant evidence on government interventions for innovation as: "for each effective government intervention, there have been dozens, even hundreds, of failures, where substantial public expenditures bore no fruit."

\section{Attempts to correct market failure result in policy failure}

The results reviewed above suggest that positive effects of innovation policies are often exaggerated and that outcomes in terms of more innovations, entrepreneurship and growth have been disappointing. In this section, we explain these results theoretically. As outlined previously, innovation policies draw legitimacy from the existence of market failures in investments in and commercialization of new knowledge, meaning that firms will underinvest in $R \& D$ due to difficulties in appropriating the potential gains of those investments, leading to a societal suboptimal level of welfare-generating R\&D. However, the presumed existence of a market failure is a necessary but insufficient criterion for public intervention. The criterion is insufficient because the government's ability to solve market failures presupposes the absence of policy failures. An alleged market failure is not an adequate reason for political intervention: It also requires demonstrating that politics really can solve the problem in question, i.e. avoiding policy failures. This is an important but less often considered challenge for innovation policy. Challenges can be divided into information problems and incentive 
problems (Buchanan and Tollison 2009; Karlson 1993; Boettke and Leeson 2004; Leeson and Subrick 2006; Pennington 2011).

\subsection{Information problems}

Information problems concern the difficulty a public actor face in collecting the information and acquiring the knowledge enabling correct decision-making regarding, for example, the allocation of resources. As Hayek (1945) showed, it is practically impossible to aggregate information and knowledge about production conditions, business opportunities, customer preferences, etc. to any central unit in society. Such information is dispersed, local, and time-bound in character, even in today's modern digital economy. With regard to innovation policy and the results reviewed above, there are numerous implications of Hayek's argument.

First, the existence of a market failure is empirically difficult to prove, or measure. The original argument by Arrow (1962) was of a theoretical nature and has not been validated. One could expect the potential size of such a market failure to vary greatly depending upon institutional characteristics, industrial context, regional and national setting. Such differences along with the fact that it is a very methodologically challenging task to locate and compute the size of a market failure means that policymakers are put in the awkward position of trying to solve a problem that is unknown both in terms of its existence, size and location. Needless to say, such a situation is almost bound to result in malinvestments.

The second implication concerns that a market economy is more compatible with the notion of dispersed knowledge than a public policy intervention. Industrial development in a market economy characterized by innovations is often described as a complex evolutionary process (Nelson and Winter 1982). Through experimental search characterized by failures and unpredictable breakthroughs, the economy develops over time (Aldrich 1999). Individual market actors make mistakes and invest in the wrong technical solution or the wrong business model for a new technology (Delmar et al. 2011). If the actors themselves who operate in a market are unable to know which technology or business model is optimal, there is reason to question how a public actor in the form of a government agency or a policymaker can perform this task satisfactorily. Government involvement in the form of "picking winners," that is, attempts to generate growth through government selection of technologies or firms, risks becoming expensive for taxpayers (Lerner 2009). Previous research has shown that venture capital investments tend to be highly spatial and build on social networks (Hochberg et al. 2007). The price mechanism provides aggregate information about customers' demand, and the firms' profits and losses. Information and knowledge are thus conveyed and generated among market actors in competitive markets who are nested together through social, economic and technological interdependencies, and this information is hard to extract from its origin and locate in a central policy unit.

\subsection{Incentive problems}

Incentive problems concern whether policies can be designed in a way that is compatible with incentive structures throughout society. Any policy implementation needs to consider the extent to which political decision makers, administrators and commercial 
forces are driven by incentives that make policies work out as intended. The literature on political economy often highlights public actors' goal setting as a matter of aligning between different types of interests, including the vote maximizing behavior of politicians and budget maximizing among government agencies. Moreover, politics and public grants in particular are frequently influenced by lobbying of special interest groups at the expense of taxpayers and the public (Niskanen 1975).

Incentive problems help us explain some of the results regarding why public policies for innovation have delivered meagre results. Different public programs tend not to be closed down, even when they have no positive effects, arguably due to the budget maximizing nature of government agencies and the need of politicians to appear as decisive. Government initiatives can also lead to firms developing opportunistic behaviors which, ultimately, can result in both cheating and corruption. A recent German study found that soft loans have not necessarily gone to firms that need them most, but to firms where management have personal connections to funding agencies (Haselmann et al. 2018).

Furthermore, even support or cheap loans are not free as they are always associated with a search process that requires personnel resources, both for the firm and the administrative body. Competition may be distorted, and selective support can create skewed incentives where firms spend more time applying for grants and lobbying for support than they do developing their products and services (Baumol 1990). There is also a risk that politicians prioritize what benefits them in the short term rather than making decisions that benefit society in the long term. There is always a risk, then, that support schemes and an active innovation policy will be exploited by opportunistic politicians as well as authorities and firms. One example comes from contemporary developments in Spain, where an overly supportive scheme for renewable energy resulted in a bubble of solar cells and wind power, as well as considerable levels of corruption. The support was so generous that growth became unmanageable for the government, which eventually had to withdraw the support it had assured would apply for years to come (Alvarez et al. 2009). This shows that public initiatives for innovation are associated with considerable incentive problems.

To sum up, there are several theoretical arguments why a market's conditions would produce an insufficient supply of innovation, suggesting that policy efforts are needed. These are, however, associated with their own difficulties, both with regard to access to relevant information and incentives of the actors involved. The fact that innovation is important for the economy therefore does not imply that R\&D or specific firms should be supported by authorities. A functioning policy for growth therefore needs to strike a balance: Policy failures may be as problematic as market failures.

\subsection{Explaining the prevalence of innovation support policies}

Despite the empirical evidence reviewed in this paper and the well-established theoretical edifices related to information and incentive problems, active and targeted innovation support policies are becoming increasingly popular. How can this be the case?

An explanation for the policy trend is that targeted support initiatives are easy to justify politically (Potts et al. 2016). Politicians appear decisive and committed to a cause when they launch a new support structure and state that billions of euros or dollars will be invested in innovation and entrepreneurship. Beneficiaries of such 
policies include politicians, government agencies and the firms that thrive on these support schemes, who congeal into concentrated interest groups. The cost, however, is distributed across a large and immobilised group in the form of taxpayers and other firms who instead concentrate their attention on serving customers and improving their operations. Unfortunately, policies that have limited effects but strong proponents and are politically easy to justify may prevail in the long term, despite their ineffectiveness. Conversely, escaping a trap of subsidy and privilege is difficult. It is hard to remove regulatory burden, labor market restrictions, and other barriers to innovation and entrepreneurship. The benefits of liberalization are distributed over large and unidentified groups. Reformers need to be deal with vested interest groups that have or think they have a lot to lose from the enactment of new policies. A competitive market economy is most likely a more genuine public good than R\&D.

\section{Discussion: New theoretical approaches to innovation}

Given the stark evidence against the effectiveness of various targeted innovation policies, one must ask to what extent this is a problem in design of such policies or a more fundamental problem in that they are based on faulty theoretical premise? We here argued for the latter. Market failures in innovation are not the key impediment for innovations in society and may never have been.

Research in the fields of open innovation (e.g. Von Hippel 2005), knowledge commons (e.g. Frischmann et al. 2014), and intellectual property (e.g Boldrin and Levine 2002) all emphasize that organizations and markets regularly work their way around knowledge investment and appropriation problems. What is emerging instead is a new theoretical approach to the innovation problem that emphasizes coordination and knowledge problems rather than resource allocation problems, and that draws on evolutionary economics, Austrian market-process theory, and new institutional economics (see e.g. Davidson and Potts 2016). These new theoretical models emphasize that the economic problem is the discovery of value not invention of new technology. The focus therefore is on the innovation problem in a market context, rather than on the invention problem in an organizational context.

The new approaches, which as already has been noted largely builds on the contributions of Schumpeter, Hayek and Kirzner, emphasize the role of entrepreneurship in the market discovery process and the role of institutions to coordinate such discovery, and they focus attention on the barriers to innovation that come from within the economy, particularly regulatory and political constraints. They find that innovation resources are more than just the technical details of an invention but also crucially include market information about the nature of the entrepreneurial opportunity.

To explain how innovations are introduced, Nelson and Winter (1982, p. 119-121) suggested that it is the departure of employees with idiosyncratic knowledge from a plant that causes the 'mutation' of an existing routine, both in an old plant and in the new organization. From this perspective, labor mobility on a competitive labor market is an essential mechanisms for dissemination of knowledge relevant for innovations to occur, since that knowledge is embedded in individuals (Wennberg 2009). Recent large-scale studies provide evidence in favor of this theory by showing that in US states that have non-compete covenants to disincentivice skilled personnel to change 
employers, patenting behavior is more rare (Marx 2011; Marx et al. 2015). European evidence also indicates that in national states with higher labor market regulations, innovative entrepreneurship tends to be less prevalent (Fu and Larsson 2018).

The commercial exploitation of new knowledge is an equally important ingredient in economic growth as the creation of new knowledge through R\&D and the like (Romer 1994). New knowledge comes from things that people do. They create new knowledge because they think they may be able to achieve market power and earn monopoly rents. The question then becomes who the agents are that are most likely to create the new knowledge and introduce it to the market for commercial ends, and why do they do this. Awareness about the existence of this knowledge is not necessarily free or equally distributed across all individuals in an economy. On the contrary, as Hayek (1945) pointed out, a central feature of a market economy is the division of knowledge among individuals, as no two individuals share the same knowledge or information at the same point in time. What is important is that new knowledge is diffused and generated in the economy through the market process, not that it is equally available to everyone.

Given the vital need for independent actors' decisions to exploit new knowledge for commercial purposes, the state's role is to secure the conditions of free and competitive markets rather than to seek to identify or steer who exploits this knowledge, and how.

Moreover, it needs to be emphasized that there is no automatic logic suggesting that the differences in access to knowledge will lead to the successful exploitation of that knowledge. On the contrary, those that are the most successful in identifying potentially valuable opportunities are far removed from those most capable of exploiting them (Schumpeter 1934). A long line of influential work beginning with Vannevar Bush (1945), has argued that government support for basic science is necessary to create new technologies and industries. This is perhaps best exemplified with knowledge arising from public investments such as university research, where professor-led commercialization attempts are on average by far the least successful compared to commercialization attempts led by industrially experienced actors (e.g. Wennberg and Wiklund 2011). The distinctive role of different actors in identifying and exploiting new knowledge for commercial purposes is not distinct for university innovations but broadly applicable in the economy. For example, an important role of the venture capital industry is to identify entrepreneurs with valuable opportunities and to match them with human and financial resources needed to organize the exploitation of that opportunity (Gompers and Lerner 1999).

\section{Conclusions}

In a world of technological change and global competition, economies struggle to remain competitive. Inspired by popular but theoretically incomplete and empirically weakly founded notions of "the entrepreneurial state", the European Union and other political entities have sought to address this challenge through various industrial and innovation policies such as targeted support schemes, research \& development (R\&D) grants and subsidies. In this paper we contrasted such a notion of an "entrepreneurial state" with other contemporary and classical theories on innovation that put the emphasis on entrepreneurship and market processes highlighting several deficiencies in the notion of an entrepreneurial state. 
The entrepreneurial state relies on the theory of market failure that assumes that 'the innovation problem' is in essence an allocation problem in funding R\&D. The policy implication is that the misallocation (compared to a fictional social welfare optima) can be resolved with a reallocation of scarce economic resources. This suggests a role for centrally placed bureaucrats in supporting innovation by targeted spending of public resources. In this paper, we have reviewed and discussed empirical results suggesting that this logic is flawed. Having covered a considerable body of research suggesting that various innovation support schemes have limited positive effects, we explain these results by drawing upon information and incentive problems.

The information problem implies that market failures cannot be measured or properly located, meaning that attempts to resolve them are bound to be misallocated in terms of size and scope. Moreover, the notion of dispersed knowledge suggests that central policymakers cannot substitute a decentralized market process (Hayek 1945). The incentive problem posits that innovation policies may often result in unintended outcomes as self-interested behavior among policymakers and firms alike generate distortions and opportunistic behavior. In sum, the presence of information and incentive problems imply that attempts to resolve market failure instead result in policy failure.

We have argued that the market failure approach suffers from an exclusive focus on knowledge creation as it ignores the equally important mechanisms of knowledge dissemination and creation through commercial exploitation in markets, and instead suggest a more theoretically germane role of the state in securing the conditions of free and competitive markets. Based on central perspectives in innovation economics and a long time of empirical results, this provides a stronger foundation for a more innovative economy than alternative perspectives ignoring central economic priors and without due empirical basis, such as notions of an Entrepreneurial State. Only by doing less and do it better can governments help unleash - rather than steer - the welfaregenerating engine of the free-market Innovation machine (Baumol 2002).

Funding Information Open access funding provided by Chalmers University of Technology.

Open Access This article is licensed under a Creative Commons Attribution 4.0 International License, which permits use, sharing, adaptation, distribution and reproduction in any medium or format, as long as you give appropriate credit to the original author(s) and the source, provide a link to the Creative Commons licence, and indicate if changes were made. The images or other third party material in this article are included in the article's Creative Commons licence, unless indicated otherwise in a credit line to the material. If material is not included in the article's Creative Commons licence and your intended use is not permitted by statutory regulation or exceeds the permitted use, you will need to obtain permission directly from the copyright holder. To view a copy of this licence, visit http://creativecommons.org/licenses/by/4.0/.

\section{References}

Acs, Z. J. (2002). Innovations and the growth of cities. Edward Elgar.

Aldrich, H. (1999). Organizations evolving. London: Sage Publications.

GC Alvarez, RM Jara, JRR Julián, JIG Bielsa (2009) Study of the effects on employment of public aid to renewable energy sources Universidad Rey Juan Carlos https://wwwsolaripediacom/files/844pdf

Amezcua AS (2010) Boon or boondoggle? Business incubation as entrepreneurship policy vol http://surface. syr.edu/ppa_etd/80/. Doctoral thesis in Public Administration. Syracuse University. http://surface.syr. edu/ppa_etd/80/, 
K Arrow (1962) Economic welfare and the allocation of resources for invention. In: The rate and direction of inventive activity: Economic and social factors. Princeton University press, pp 609-626

Audretsch, D. (1995). Innovation and industry evolution. MIT press. Cambridge, Mass. ; London.

Audretsch, D. (2008). The entrepreneurial society. Oxford: Oxford Uiversity Press.

Audretsch, D., \& Baumol, W. (2001). Burke a. Competition policy in dynamic markets International Journal of Industrial Organization, 19, 613-634.

Baumol, W. J. (1990). Entrepreneurship: Productive, unproductive, and destructive. Journal of Political Economy, 98, 893-921.

Baumol, W. J. (2002). The free-market innovation machine: Analyzing the growth miracle of capitalism. Princeton: Princeton University press.

Bennett, R. (2008). SME policy support in Britain since the 1990s: What have we learnt? Environment and Planning. C, Government \& Policy, 26, 375-397.

Boettke, P. J., \& Leeson, P. T. (2004). Liberalism, socialism, and robust political economy. Journal of Markets and Morality, 7, 99-111.

Boldrin, M., \& Levine, D. (2002). The case against intellectual property American economic review., 92, 209212.

S Box (2009) OECD work on innovation-a stocktaking of existing work

Brown, J. D., \& Earle, J. S. (2017). Finance and growth at the firm level: Evidence from SBA loans the journal of finance., 72, 1039-1080.

Bruneel, J., Ratinho, T., Clarysse, B., \& Groen, A. (2012). The Evolution of Business Incubators: Comparing demand and supply of business incubation services across different incubator generations Technovation, $32,110-121$.

Buchanan, J., \& Tollison, R. (2009). The theory of public choice - II. Ann Arbor: The University of Michigan Press.

V Bush (1945) Science the endless frontier: A report to the president on a program for postwar scientific research

Colombo, M. G., \& Grilli, L. (2011). Murtinu S. R\&D subsidies and the performance of high-tech start-ups Economics Letters, 112, 97-99.

Commission E (2020) Financing the green transition: The European Green Deal Investment Plan and Just Transition Mechanism https:/eceuropaeu/regional_policy/en/newsroom/news/2020/01/14-01-2020-financing-the-green-transition-the-european-green-deal-investment-plan-and-just-transition-mechanism

Cumming, D., \& Groh, A. P. (2018). Entrepreneurial finance: Unifying themes and future directions Journal of Corporate Finance, 50, 538-555.

Davidson, S., \& Potts, J. (2016). A new institutional approach to innovation policy Australian Economic Review, 49, 200-207.

Delmar, F., Wennberg, K., \& Hellerstedt, K. (2011). Endogenous growth through knowledge spillovers in entrepreneurship: An empirical test. Strategic Entrepreneurship Journal, 6(3), 199-226.

Dimos, C., \& Pugh, G. (2016). The effectiveness of R\&D subsidies: A meta-regression analysis of the evaluation literature research policy., 45, 797-815.

Djankov S, LaPorta R, Lopez-de-Silanes F, Shleifer A (2002) The regulation of entry quarterly journal of economics 117:1-37

O Ejermo (2018) Does incubation lead to innovation? Evidence from the Swedish incubation program. https://www.tillvaxtanalys.se/download/18.347b5cf7166740f99f173c83/1542627788370 /pm\%202018_20_Does\%20incubation\%20lead\%20to\%20innovation.pdf

Frischmann, B. M., Madison, M. J., \& Strandburg, K. J. (2014). Governing knowledge commons. Oxford University Press.

Fu, K., \& Larsson, A.-S. (2018). Wennberg K, Habitual entrepreneurs in the making: How labour market rigidity and employment affects entrepreneurial re-entry small business economics., 51, 465-482.

García-Quevedo, J. (2004). Do public subsidies complement business R\&D? A meta-analysis of the econometric evidence Kyklos, 57, 87-102.

Gompers, P. A., \& Lerner, J. (1999). The venture capital cycle. Cambridge, MA: MIT Press.

Gustafsson, A., Stephan, A., Hallman, A., \& Karlsson, N. (2016). The "sugar rush" from innovation subsidies: A robust political economy perspective. Empirica, 43, 729-756.

Gustafsson, A., Tingvall, P.G. \& Halvarsson, D. (2019) Subsidy Entrepreneurs: an Inquiry into Firms Seeking Public Grants. J Ind Compet Trade. https://doi.org/10.1007/s10842-019-00317-0.

Haselmann, R., Schoenherr, D., \& Vig, V. (2018). Rent seeking in elite networks journal of political economy., 126, 1638-1690.

Hayek, F. A. (1945). The use of knowledge in society. American Economic Review, 35, 519-530. 
Hochberg, Y. V., Ljungqvist, A., \& Lu, Y. (2007). Whom you know matters: Venture capital networks and investment performance the journal of finance., 62, 251-301.

Howell, S. T. (2017). Financing innovation: Evidence from R\&D grants American economic review., 107, $1136-1164$.

Hussinger, K. (2008). R\&D and subsidies at the firm level: An application of parametric and semiparametric two-step selection models journal of applied econometrics., 23, 729-747.

Karlson, N. (1993). The state of state. In An inquiry concerning the role of invisible hands in politics and civil society (1993). Stockholm: Almquist \& Wiksell International.

Kirzner, I. (1973). Competition \& entrepreneurship. Chicago: Chicago University Press.

Klette, T. J., Møen, J., \& Griliches, Z. (2000). Do subsidies to commercial R\&D reduce market failures? Microeconometric evaluation studies Research policy, 29, 471-495.

Klofsten, M., Lundmark, E., Wennberg, K., \& Bank N. (2020). Incubator specialization and size: Divergent paths towards operational scale technological forecasting and social change., 151, 119821.

Lach, S. (2002). Do R\&D subsidies stimulate or displace private R\&D? Evidence from Israel The journal of industrial economics, 50, 369-390.

Leeson, P. T., \& Subrick, J. R. (2006). Robust political economy The Review of Austrian Economics, 19, 107111.

Lerner, J. (2009). Boulevard of broken dreams: Why public efforts to boost entrepreneurship and venture capital have failed-and what to do about it. Princeton University Press.

Lukeš, M., Longo, M. C., \& Zouhar, J. (2019). Do business incubators really enhance entrepreneurial growth? Evidence from a large sample of innovative Italian start-ups Technovation, 82, 25-34.

Marx, M. (2011). The firm strikes back non-compete agreements and the mobility of technical professionals. American Sociological Review, 76, 695-712.

Marx, M., Singh, J., \& Fleming, L. (2015). Regional disadvantage? Employee non-compete agreements and brain drain Research Policy, 44, $394-404$.

M Mazzucato (2015) The entrepreneurial state: Debunking public vs. private sector myths. Anthem press,

Nelson, R., \& Winter, S. (1982). An evolutionary theory of economic change. Cambridge, MA: Belknap Press.

Niskanen, W. A. (1975). Bureaucrats and politicians. The Journal of Law and Economics, 18, 617-643.

Pennington, M. (2011). Robust political economy Policy: A Journal of Public Policy and Ideas, 27, 8.

Potts J, Allen DW, MacDonald T (2016) keep your friends close, your enemies closer: The case for inclusive innovation policy your enemies closer: The case for inclusive innovation policy (September 7, 2016)

Romer, P. M. (1994). The origins of endogenous growth the. Journal of Economic Perspectives, 8, 3-22.

Sandström, C. (2015) Book review: the entrepreneurial state (Anthem Press, 2013), Ekonomisk Debatt, No 3 , p. $92-94$.

Sandström, C., Wennberg, K., Wallin, M. W., \& Zherlygina, Y. (2016). Public policy for academic entrepreneurship initiatives: A review and critical discussion. The Journal of Technology Transfer, 43, 12321256.

Schumpeter, J. A. (1934). The theory of economic development. Cambridge, Mass: Harvard University Press.

Schwartz, M. (2013). A control group study of incubators' impact to promote firm survival. The Journal of Technology Transfer, 38, 302-331.

Shapiro, C. (2001). Navigating the patent thicket: Cross Licences, patent pools, and standard-setting. In A. Jaffe, J. Lerner, \& S. Stern (Eds.), Innovation policy and the economy, vol 1. Boston: MIT Press.

Von Hippel, E. (2005). Democratizing innovation: The evolving phenomenon of user innovation. Cambridge: MIT Press.

SJ Wallsten (2000) The effects of government-industry R\&D programs on private R\&D: the case of the Small Business Innovation Research program.RAND Journal of Economics:82-100

Wennberg, K. (2009). Knowledge combinations and the survival of financial services ventures. Journal of Evolutionary Economics, 19(2), 259-276.

Wennberg, K., \& Wiklund, J. (2011). Wright M. The effectiveness of university knowledge spillovers: Performance differences between university spinoffs and corporate spinoffs Research Policy, 40, 11281143.

B Widerstedt, J Månsson (2015) Can business counselling help SMEs grow?: evidence from the Swedish business development grant programme Journal of small business and enterprise development 22:652665

Wiggins, S. N. (1995). Entrepreneurial enterprises, endogenous ownership, and the limits to firm size. Economic Inquiry, 33, 54-69.

Zúñiga-Vicente, J. Á., Alonso-Borrego, C., Forcadell, F. J., \& Galán, J. I. (2014). Assessing the effect of public subsidies on firm R\&D investment: A survey journal of economic surveys., 28, 36-67. 
Publisher's note Springer Nature remains neutral with regard to jurisdictional claims in published maps and institutional affiliations.

\section{Affiliations}

\section{Nils Karlson ${ }^{1} \cdot$ Christian Sandström $^{2} \cdot$ Karl Wennberg ${ }^{3}$}

Christian Sandström

christian.sandstrom@ratio.se

Karl Wennberg

Karl.wennberg@liu.se

1 Ratio Institute, Linköping University, Stockholm, Sweden

2 Science and Technology Studies, Jönköping International Business School, Ratio institute and Chalmers University of Technology, Stockholm, Sweden

3 Division of Business Administration, Linköping University, Ratio institute, Stockholm, Sweden 